\title{
PENDAMPINGAN FOTO PRODUK UMKM KOMUNITAS SAUNG TALEUS DI KOTA BOGOR MENGGUNAKAN PONSEL CERDAS
}

\author{
Handika Dany Rahmayanti ${ }^{1 *}$, Muhammad Halim² ${ }^{2}$ Ferdiansyah $^{2}$, Septia Ardiani' ${ }^{1}$, dan \\ Nurul Akmalia ${ }^{3}$
}

${ }^{1}$ Prodi Teknik Kemasan, Politeknik Negeri Media Kreatif, Indonesia

${ }^{2}$ Prodi Fotografi, Politeknik Negeri Media Kreatif, Indonesia

${ }^{3}$ Prodi Penerbitan, Politeknik Negeri Media Kreatif, Indonesia

*Email: handikadany@polimedia.ac.id

\begin{abstract}
ABSTRAK
Abstrak: Produk umkm binaan Saung Taleus banyak memasarkan produknya secara online melalui beberapa marketplace maupun laman media sosial. Permasalahannya keterampilan UMKM binaan Saung Taleus dalam fotografi produk sangat rendah. Hal ini terbukti dari foto-foto produk mereka yang dipasarkan di sosial media terlihat kurang menarik. Dengan adanya foto produk yang menarik menjadi salah satu strategi pemasaran yang jitu di tengah ketatnya persaingan pasar digital. Workshop foto produk diperlukan agar foto produk mitra terlihat menarik sehingga mempengaruhi keputusan pembelian konsumen. Pada kegiatan pelatihan ini kami melatih peserta mengenai teknik-teknik dasar fotografi beserta komposisinya. Peserta dibekali dengan fotografi kit seperti ring light, tripod dan mini studio box. Untuk mengambil gambar, peserta menggunakan ponsel masing-masing. Pelatihan ini cukup berhasil yang ditunjukkan oleh antusiasme para peserta pelatihan dan menghasilkan beberapa fotografi produk yang sangat bagus.
\end{abstract}

Kata Kunci: workshop, fotografi, ponsel cerdas, dan, Saung Taleus

Abstract: The MSME products fostered by Saung Taleus market a lot of their products online through several marketplaces and social media pages. The problem is that the skills of SMEs assisted by Saung Taleus in product photography are very low. This is evident from the photos of their products marketed on social media that look less attractive. Having attractive product photos is one of the most effective marketing strategies in the midst of intense digital market competition. Product photo workshops are needed so that partner product photos look attractive so that they influence consumer purchasing decisions. In this training activity we train participants on the basic techniques of photography and its composition. Participants are provided with a photography kit such as a ring light, a tripod and a mini studio box. To take pictures, participants use their respective cell phones. The training was quite successful as demonstrated by the enthusiasm of the trainees and resulted in some excellent product photography.

Keywords: workshops, photography, smartphones and, Saung Taleus

\section{A. LATAR BELAKANG}

Saung Taleus merupakan kelompok dibawah binaan Dinas Ketahanan Pangan Kabupaten Bogor. Saung Taleus berlokasi di kampung Cibogo RT 004/RW 008, Desa Tugu Jaya, Kecamatan Cigombong, Kabupaten Bogor. Kelompok ini telah mendapatkan persetujuan baik Bupati Bogor maupun dari Dinas Ketahanan Pangan. Kelompok ini bertujuan mengembangkan pangan lokal khas Bogor yakni talas, menguatkan kembali talas sebagai sebagai tanaman dan panganan khas Bogor, mengurangi ketergantungan penggunaan bahan dasar terigu (gandum), meningkatkan kesejahteraan petani talas 
dengan cara melibatkan dalam pengembangan budi daya talas serta kepastian hasil panen, mengumpulkan UMKM yang menggunakan talas sebagai bahan dasar/tambahan, berperan aktif dalam ekonomi di wilayah sekitar. Pemasaran produk UMKM binaan saung taleus salah satunya dengan menjual produknya di Gerai Pangan Lokal milik Bada Pengelola Alih Teknologi Pertanian di kota Bogor. Selain itu produk umkm binaan Saung Taleus banyak memasarkan produknya secara online melalui beberapa marketplace maupun laman media sosial. Permasalahannya keterampilan UMKM binaan Saung Taleus dalam fotografi produk sangat rendah. Hal ini terbukti dari foto-foto produk mereka yang dipasarkan di sosial media terlihat kurang menarik. Seperti kita ketahui bersama, strategi pemasaran sering kali diibaratkan sebagai jantung kehidupan sebuah usaha (Purwanto dan Veranita, 2018). Dengan adanya foto produk yang menarik menjadi salah satu strategi pemasaran yang jitu di tengah ketatnya persaingan pasar digital. Workshop foto produk diperlukan agar foto produk mitra terlihat menarik sehingga mempengaruhi keputusan pembelian konsumen. Selain itu foto yang menarik juga diperlukan agar mereka dapat bersaing dan memenangkan persaingan di pasar elektronik.

\section{B. METODE PELAKSANAAN}

Metode pelaksanaan yang digunakan dalam proses keseluruhan kegiatan pengabdian kepada masyarakat ini meliputi tahapan pra-kegiatan, pelaksanaan, sampai kepada paska kegiatan seperti yang ditunjukkan Gambar 1. Tahapan ini untuk menjadi panduan bagi tim dalam melaksanakan kegiatan pengabdian, serta melakukan transfer dari solusi yang ditawarkan oleh tim kepada mitra.

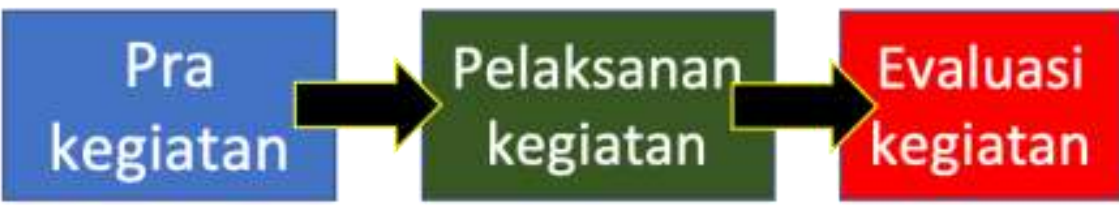

\begin{tabular}{|c|c|}
\hline $\begin{array}{l}\text { 1. Audiensi dengan } \\
\text { pihak mitra }\end{array}$ & $\begin{array}{l}\text { 1. Penyampaian } \\
\text { materi }\end{array}$ \\
\hline 2. Penentuan & 2. Praktek dasar \\
\hline masalah & 3. Diskusi dengan \\
\hline $\begin{array}{l}\text { 3. Pengajuan } \\
\text { proposal }\end{array}$ & peserta \\
\hline 4. Persiapan materi & \\
\hline $\begin{array}{l}\text { 5. Menentukan waktu } \\
\text { pelaksanaan }\end{array}$ & \\
\hline
\end{tabular}
1. Evaluasi kegiatan pelatihan
2. Pembuatan laporan
3. Publikasi hasil kegiatan

Gambar 1. Metode Pelaksanaan

Kegiatan dibagi ke dalam tiga tahap besar, yaitu sebelum kegiatan atau pra-kegiatan, pelaksanaan kegiatan, dan setelah kegiatan. Tahapan pra-kegiatan dimulai dengan melakukan audiensi dengan pihak mitra, audiensi dilakukan untuk meminta persetujuan dalam bentuk surat pernyataan, kemudian memetakan masalah yang dimiliki mitra dan menentukan solusi dari permasalahan tersebut Pada tahap ini juga dicari kesepakatan antara tim dan mitra mengenai waktu pelaksanaan dari kegiatan sekaligus bentuk partisipasi mitra dalam kegiatan tersebut.

\section{HASIL DAN PEMBAHASAN}

Salah satu hambatan yang ditemui oleh UMKM selama pandemik COVID-19 adalah pemasaran. Dengan pesatnya perkembangan teknologi informasi dan komunikasi dewasa 
ini, pemasaran UMKM harus mampu memanfaatkan pemasaran berbasis online, baik itu melalui pembukaan toko online, apikasi penjualan online maupun promosi dan pemasaran produk UKM dengan memanfaatkan jejaring sosial, sehingga bisa menjadi media yang bisa mewakili produk yang dibutuhkan oleh konsumen (Febriyantoro, 2020). Untuk meningkatkan kemampuan mitra dalam dokumentasi foto produk, serta meningkatkan kemampuan dalam editing foto produk yang nantinya akan digunakan dalam pemasaran online diperlukan pelatihan foto produk.

Pada kegiatan pengabdian kepada masyarakat ini telah dilakukan pendampingan berupa workshop foto produk menggunakan ponsel cerdas kepada UMKM di bawah kelompok Saung Taleus dan beberapa UMKM kota Bogor. Peserta workshop berjumlah 30 orang. Kegiatan dilakukan secara luring pada hari Rabu tanggal 6 Oktober dan bertempat di Hotel Ibis Bogor dengan mengikuti protokol kesehatan seperti peserta diwajibkan memakai masker, pengecekan suhu badan dan diwajibkan memakai hand sanitizer sebelum memasuki ruangan. Kegiatan dibuka oleh Direktur Politeknik Negeri Media Kreatif sebagai bentuk dukungan kampus atas terselenggaranya kegiatan ini serta sambutan dari Kepala P3M Polimedia dan Perwakilan Balai Pengelola Alih Teknologi Pertanian sebagai instansi yang memfasilitasi Saung Taleus dan UMKM kota Bogor. Beberapa dokumentasi kegiatan pelatihan fotografi produk menggunakan ponsel cerdas untuk kelompok Saung Taleus dan UMKM kota Bogor ditunjukkan Gambar 2.
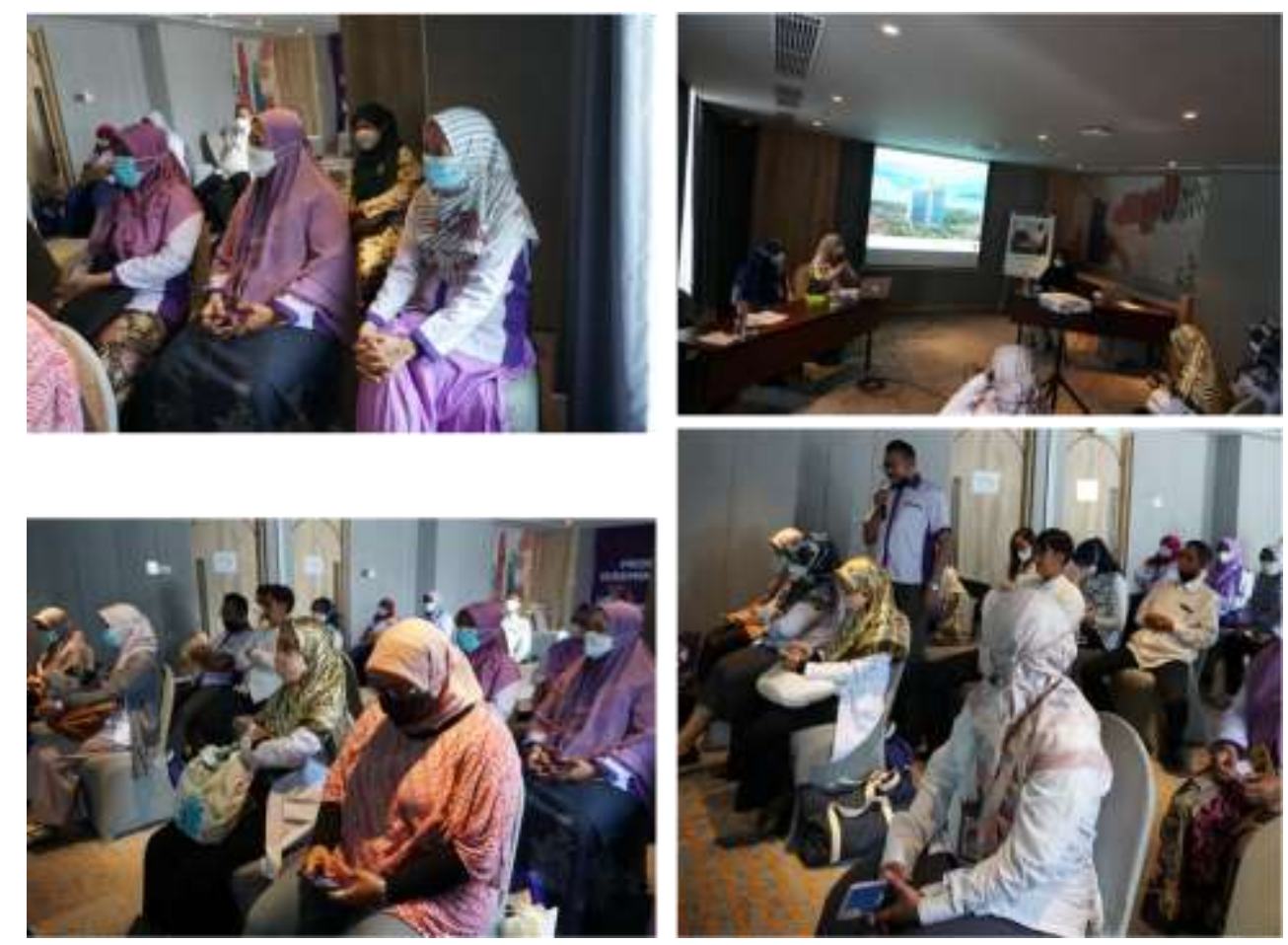

Gambar 2 Dokumentasi Kegiatan Workshop Foto Produk

Di era serba digital fotografi dapat dimulai dengan menggunakan ponsel cerdas. Bahkan tren industri perfilman Hollywood telah mulai memproduksi film dengan menggunakan kamera dari ponsel cerdas. (Dewi, 2016). Pelatihan fotografi meliputi teori dan praktek tentang, yaitu: (1) Pengertian fotografi; (2) Pengenalan atas jenis-jenis fotografi; (3) segitiga exposure; (4) Teknik - teknik dasar fotografi beserta komposisinya (Gunawan, 2014). Pada kegiatan pelatihan ini kami melatih peserta mengenai teknikteknik dasar fotografi beserta komposisinya. Peserta dibekali dengan fotografi kit seperti 
ring light, tripod dan mini studio box. Untuk mengambil gambar, peserta menggunakan ponsel masing-masing.

Beberapa teknik fotografi juga diajarkan saat pelatihan adalah zooming, panning, freezing, makro, siluet, bulb, komposisi dari field of view, dan sudut pengambilan gambar atau komposisi. Dokumentasi beberapa teknik fotografi yang diberikan saat pelatihan ditunjukkan Gambar 3. Setelah pemberian materi, acara dilanjutkan dengan sesi diskusi dan tanya jawab fotografi praktis menggunakan ponsel cerdas dan tips untuk fotografer pemula. Target dari kegiatan ini adalah adanya peningkatan kesadaran, pengetahuan, dan kemampuan anggota Saung Taleus dan UMKM kota Bogor dalam hal fotografi dilihat dari sisi komunikasi visual.
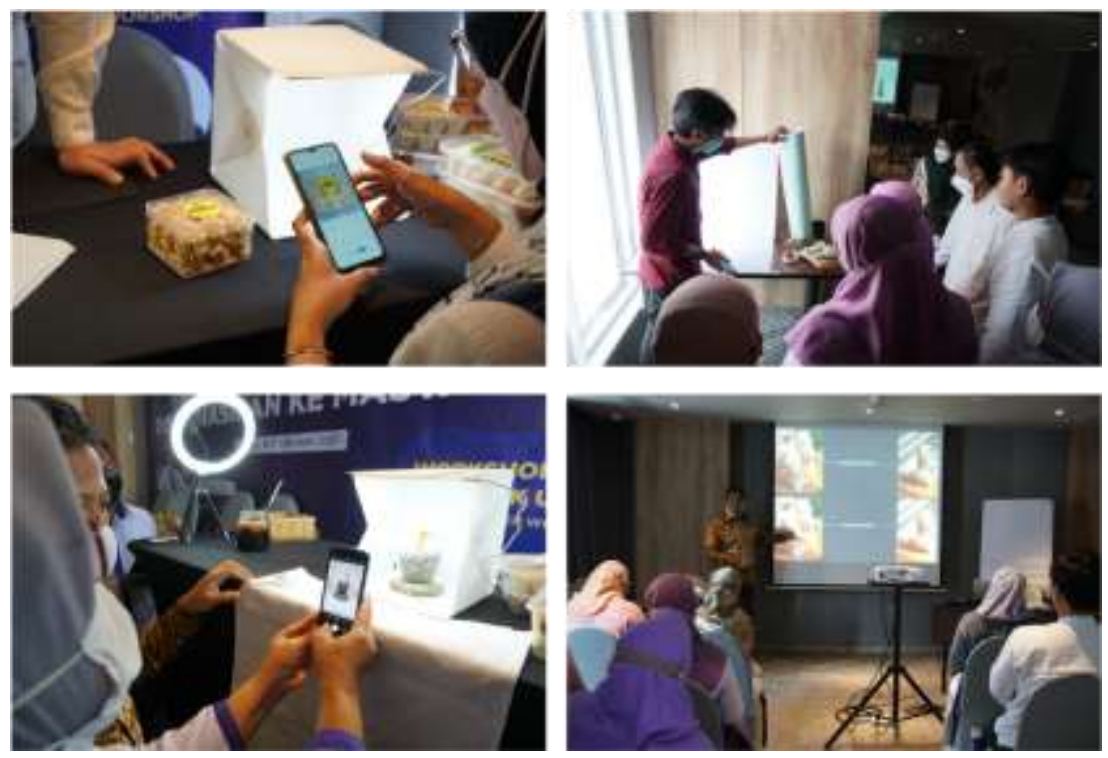

Gambar 3 Penjelasan Teknik Fotografi

Pelatihan ini cukup berhasil yang ditunjukkan oleh antusiasme para peserta pelatihan dan menghasilkan beberapa fotografi produk yang sangat bagus. Beberapa hasil foto dari UMKM yang mengikuti workshop foto produk ditunjukkan Gambar 4. Luaran dari pelatihan ini, masing-masing peserta mendapatkan foto terbaik untuk diunggah di laman sosial media sebagai hasil praktek dari kegiatan pelatihan. Secara keseluruhan rangkaian kegiatan berjalan dengan lancar dan baik, walaupun ada beberapa kendala seperti pencahayaan ruangan workshop yang kurang mendukung.
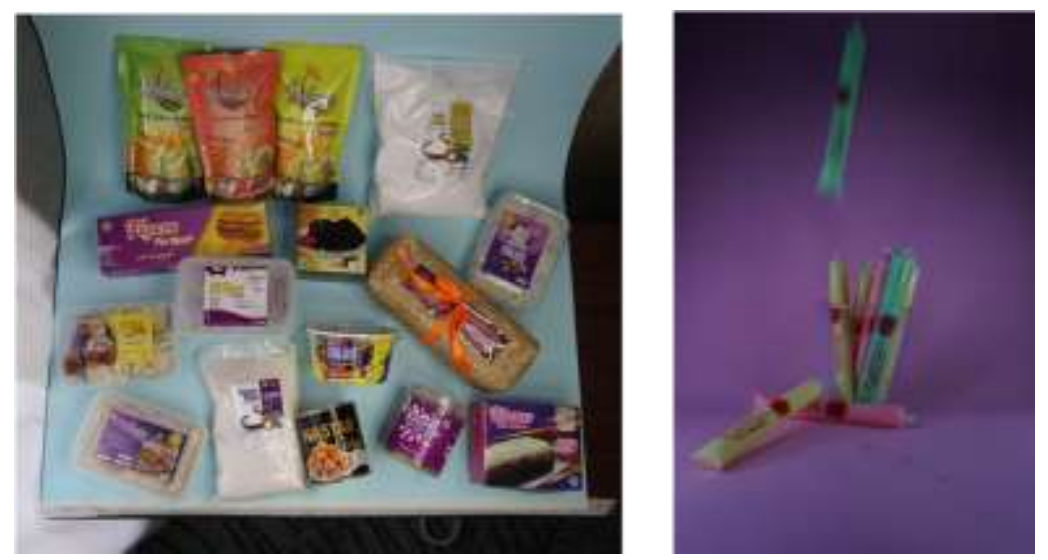

Gambar 4 Beberapa produk mitra yang mengikuti workshop 


\section{SIMPULAN DAN SARAN}

Kesimpulan yang dapat ditarik melalui kegiatan pelatihan fotografi adalah pelatihan ini merupakan sarana untuk menjalin kerjasama antara mitra dengan kampus. Mitra pada kegiatan ini adalah kelompok Saung Taleus dan beberapa UMKM kota Bogor. Secara keseluruhan rangkaian acara berjalan dengan lancar dan baik. Kegiatan pelatihan dilakukan secara luring disertai praktek pengambilan foto doleh masing-masing peserta sehingga peserta kegiatan mendapatkan pengalaman dan pembahasan secara langsung. Kegiatan pelatihan fotografi ponsel cerdas (smartphone) berhasil meningkatkan pemahaman praktis peserta mengenai fotografi produk dalam keseharian, misalnya fotografi dengan menggunakan ponsel cerdas, baik untuk pengambilan gambar dengan berfokus pada tren fotografi di media sosial, tips sederhana dengan luaran foto untuk diunggah di media sosial.

\section{UCAPAN TERIMA KASIH}

Terima Kasih kepada Badan Riset dan Inovasi Nasional (BRIN) melalui skema hibah Produk Teknologi yang Didiseminasikan ke Masyarakat (PTDM) Tahun 2021 Nomor Kontrak 011/SP2H/DPTM/DRPM/2021 dan Addendum Administrasi Kontrak Nomor 011/ADD/SP2H/DPTM/DRPM/2021.

\section{DAFTAR RUJUKAN}

Dewi, A. R. (2016). Tak diduga, 5 film keren ini ternyata dibikin dengan kamera handphone. Retrieved December 14 2021, from https://www.brilio.net/wow/tak-diduga-5-filmkerenini- ternyata-dibikin-dengan-kamera-handphone-160205i.html\#

Febriyantoro, M. T., \& Arisandi, D. (2018). Pemanfaatan digital marketing bagi usaha mikro, kecil dan menengah pada era masyarakat ekonomi ASEAN. Jurnal Riset Manajemen dan Bisnis Dewantara (JMD), 1(2), 61-76.

Gunawan, A. P. (2014). Genre Fotografi yang Diminati oleh Fotografer di Indonesia. Humaniora, $5(2), 1234-1245$.

Purwanto, Y. S., \& Veranita, M. (2018). Pelatihan Fotografi Dasar bagi Pelaku Usaha Kecil dan Menengah (UKM) Kecamatan Lengkong Kota Bandung

Putro, F. H. A. (2020). Pelatihan Fotografi di Era Digital dalam Kontek Komunikasi Visual. Jurnal Ekonomi, Sosial \& Humaniora, 1(12), 276-281.

Semuel, H., \& Setiawan, K. Y. (2018). Promosi Melalui Sosial Media, Brand Awareness,

Purchase Intention Pada Produk Sepatu Olahraga. Jurnal Manajemen Pemasaran, 12(1), 47-52. 